\title{
COMPARISON OF DIFFERENT HELIPORT SOLUTIONS FOR THE CLINICAL HOSPITAL CENTER IN OSIJEK
}

\author{
Tatjana Timko \\ Josip Juraj Strossmayer University of Osijek, Faculty of Civil Engineering Osijek, univ.bacc.ing.aedif. \\ Irena Ištoka Otković \\ Josip Juraj Strossmayer University of Osijek, Faculty of Civil Engineering Osijek, Assistant Professor \\ Corresponding author: iirena@gfos.hr
}

Professional paper / Stručni rad

\begin{abstract}
Complexity in takeoff and landing operations of helicopters require careful planning and designing of heliport infrastructure. The world's biggest aviation organization, namely Federal Aviation Administration and International Civil Aviation Organization, published their standards and designing recommendations for heliport designers to implement that are analyzed and compared in this paper. In the Republic of Croatia, helicopters are designed according to the recommendations of National heliport regulations which are based on recommendations of International Civil Aviation Organization (Annex 14). The practical part of the paper deals with the implementation of national heliport standard recommendations in two variants of heliport designs for emergency medical service for the clinical hospital center in Osijek. As a potential location of the new heliport for emergency medical transportation a transit port is analyzed because it is close to the clinical hospital center in Osijek and is well connected with the existing road infrastructure, and it is also possible to make a direct access to the hospital complex from the north side. Two solutions were analyzed and compared upon the criteria of accessibility, security of operations and possibility for instrument flight conditions, size of heliport and necessary areas, costs of building and maintenance and helicopter noise. There is an intention that regional capital cities that have clinical hospital centers need to have infrastructure for emergency helicopter transportation near the hospital.
\end{abstract}

Keywords: heliport; hospital heliport; conceptual design; National heliport regulations; ICAO; FAA

\section{USPOREDBA VARIJANTNIH RJEŠENJA HELIDROMA ZA KLINIČKI BOLNIČKI CENTAR OSIJEK}

Sažetak: Kompleksnost operacija polijetanja i slijetanja helikoptera te potrebna raspoloživost slobodnog prostora u urbanom području zahtijevaju pažljivo planiranje i projektiranje građevinske infrastrukture helidroma. Najveće svjetske zrakoplovne organizacije, Federalna uprava za zrakoplovstvo i Međunarodna organizacija za civilno zrakoplovstvo, izdale su svoje standarde i projektne preporuke kojima se projektanti helidroma služe, a koje su analizirane i uspoređene u ovome radu. U Republici Hrvatskoj helidromi se projektiraju sukladno preporukama Pravilnika o helidromima, koji je baziran na Annexu 14 Međunarodne organizacije za civilno zrakoplovstvo. Primjena preporuka koje daje Pravilnik o helidromima na praktičnom zadatku pokazana je kroz dvije varijante idejnog rješenja helidroma za potrebe Kliničkog bolničkog centra Osijek. Analizirana potencijalna lokacija za idejna rješenja je u tranzitnoj luci, zato što je u neposrednoj blizini Kliničkog bolničkog centra Osijek i dobro je povezana postojećom cestovnom infrastrukturom, a moguće je napraviti i direktan cestovni pristup području bolnice sa sjeverne strane. Dva rješenja su analizirana i uspoređena po kriterijima zračne pristupačnosti, cestovne povezanosti, zauzimanja prostora, mogućnosti instrumentalnog zračnog pristupa helidromu, sigurnosti operacija slijetanja i polijetanja, koštanja izgradnje i održavanja te buke helikoptera. Intencija je da gradovi koji su centri regije i imaju klinički bolnički centar, trebaju imati osigurane uvjete, odnosno potrebnu infrastrukturu za hitan helikopterski prijevoz u njegovoj blizini.

Ključne riječi: helidrom; bolnički helidrom; idejno rješenje; Pravilnik o helidromima; ICAO; FAA 


\section{INTRODUCTION}

Transportation using helicopters has increased globally because it is a quick and flexible way of air transportation. Furthermore, the required infrastructure for takeoff and landing of helicopters is smaller than that for airplanes. A helicopter is often used for cargo transportation, public transportation, and especially emergency transportation, such as emergency medical transportation. The intention is that most of the regional capital cities with clinical hospital centers must have the infrastructure for emergency helicopter transportation near hospitals.

In case of Osijek, an operative center for emergency medical service is placed at Aerodrome Osijek- Čepin in Čepin. Aerodrome Osijek- Čepin is located $3 \mathrm{~km}$ southeast of Osijek, and it is a sports and recreational aerodrome. Emergency transportation in unpredictable traffic conditions can take 12-15 min longer than in normal traffic conditions [1]. Placing a heliport at the Aerodrome Osijek- Čepin does not take advantage of the flexibility of helicopter transportation. The subject of this paper is the analysis of locations in urban environments near hospitals and conceptual design of heliport solutions.

National standards in the Republic of Croatia, i.e., regulations of heliports in Croatian (Pravilnik o helidromima NN 24/11) [2], are based on Annex 14 to the Convention on International Civil Aviation published by International Civil Aviation Organization (ICAO) [3]. Furthermore, there are recommendations published by Federal Aviation Administration (FAA) [4]. In this paper, recommendations for design, construction and usage of heliport, published by those two organizations, are analyzed and compared. Recommendations of Croatian regulation based on Annex 14 are implemented in the case of heliport in Osijek.

\section{ANALYSIS AND COMPARISON OF ICAO AND FAA HELIPORT DESIGN RECOMMENDATIONS}

\subsection{Comparison of recommendations for dimensioning heliport elements}

Heliports are dimensioned in accordance with the dimensions of the largest helicopter that the heliport is intended to serve (design helicopter). The main dimensions of design helicopter are: overall length of helicopter $D$, rotor diameter RD and undercarriage width dimensions UCW. In the recommendations and standards published by the organizations, FAA mostly uses overall length while ICAO uses rotor diameter as dimensioning elements $[3,4]$.

Table 1 shows the comparison of the dimensions that the organizations recommend for dimensioning operative and maneuver areas at the heliport. The minimal recommended dimension of the TLOF area is similar for both organizations $(0,83 \mathrm{D}=\mathrm{RD})$. Furthermore, the recommended minimal dimension of the FATO area with the safety area is almost equal for both the organizations, which amounts to $2 \mathrm{D}[4,5,6]$. The main differences in the recommendations are dimensions of the stand and protected areas where ICAO has stricter criterion.

Table 1 Comparison of recommended values for dimensioning heliport elements

\begin{tabular}{ccc}
\hline ELEMENT & ICAO & FAA \\
\hline TLOF & $0,83 \mathrm{D}$ & $1 \mathrm{RD}$ \\
FATO & $1 \mathrm{D}$ & $1,5 \mathrm{D}$ \\
Safety area & $2 \mathrm{D}$ & $1,5 \mathrm{D}+0,5 \mathrm{RD}$ ili $0,5 \mathrm{D}^{*}$ \\
Ground taxiway & $1,5 \mathrm{UCW}$ & $2 \mathrm{UCW}$ \\
Ground taxi-route & $1,5 \mathrm{D}$ & $1,5 \mathrm{RD}$ \\
Air taxiway & $2 \mathrm{UCW}$ & $2 \mathrm{UCW}$ \\
Air taxi-route & $2 \mathrm{D}$ & $2 \mathrm{RD}$ \\
Stand and protection area & $1,2 \mathrm{D}+0,4 \mathrm{D}$ & $1 \mathrm{RD}+0,33 \mathrm{RD}$ ili $0,5 \mathrm{RD}^{* *}$ \\
\hline
\end{tabular}

${ }^{*}$ depends on heliport type and marked area

${ }^{* *}$ depends on heliport type and parking operation 


\subsection{Comparison of recommendations for obstacle restriction and removal}

Heliport environment should not have any obstacles and should have facilities in order to provide safe helicopter operations. The purpose of the safety area is to provide an obstacle-free area for helicopters accidentally diverging from a FATO, an area for the installation of visual and non-visual aids, an area for the drainage and run-off from a FATO (Figure 1). Obstacle limitation surfaces are imaginary surfaces that surround heliport and provide clear space without obstacles. Depending on the heliport approach conditions, five types of obstacle limitation surfaces could be established: takeoff climb surface, approach surface, transitional surfaces, conical surface and inner horizontal surface.

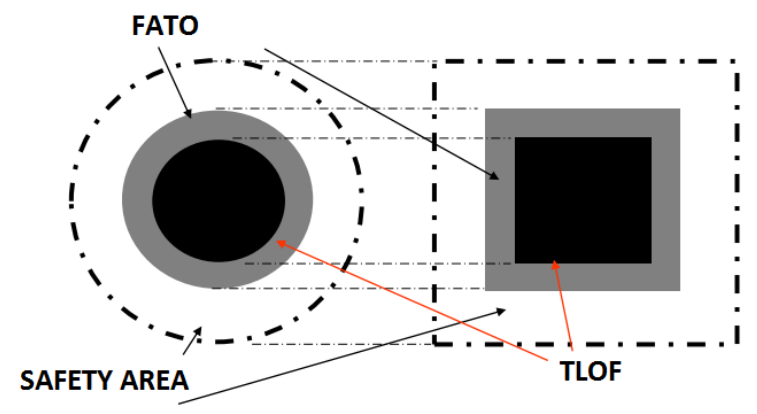

Figure 1 Safety area [5]

FAA recommendations and standards are given only for heliport design in visual approach conditions. According to this study, comparison with ICAO recommendations is only possible for establishing approach and takeoff surfaces. ICAO does not establish other surfaces in visual approach conditions, while FAA establishes a transitional surface. Table 2 shows the comparison of dimensions for construction of approach/takeoff obstacle limitation surface, recommended by FAA and ICAO. Characteristics of surface established by FAA are fixed and defined by standards, while ICAO surface characteristics depend on dimensions of design helicopter and dimensions of FATO area. FAA approach/takeoff surface is constructed of one segment, while ICAO surface is constructed of three segments that have different lengths, widths and slopes. Specified height above the elevation of the FATO area is similar in the standards of both organizations $[3,4,6]$. Comparisons of recommendations for heliport visual aids usage are described in more details in the master thesis [7].

Table 2 Comparison of recommended values for constructing obstacle limitation surfaces

\begin{tabular}{ccc}
\hline APPROACH/TAKE-OFF SURFACE & ICAO & FAA \\
\hline Width of inner edge & $2 \mathrm{D}$ & $1,5 \mathrm{D}$ \\
Divergence & $15 \%-15 \%-0 \%$ & $*$ \\
Height & $150 \mathrm{~m}$ & $152 \mathrm{~m}$ \\
Length & $245 \mathrm{~m}-7 \mathrm{RD}-{ }^{* *}$ & $1219 \mathrm{~m}$ \\
Width of outer edge & $2 \mathrm{D}+49 \mathrm{~m}-7 \mathrm{RD}-7 \mathrm{RD}$ & $152 \mathrm{~m}$ \\
Slope (maximum) & $8 \%-12,5 \%-15 \%$ & $12,5 \%$ \\
\hline
\end{tabular}

*Determined by the width of inner and outer edge

${ }^{* *}$ Determined by the specified height which amounts $150 \mathrm{~m}$

\section{CONCEPTUAL HELIPORT DESIGN FOR THE CLINICAL HOSPITAL CENTER HELIPORT}

\subsection{Analysis of location}

As a potential location of the new heliport for emergency medical transportation, a transit port is analyzed (Figure 2). It is placed on plots $8977 / 1$ and $8977 / 2$ that are close to the hospital and $3 \mathrm{~m}$ below. Currently, there are temporary buildings that can be demolished for heliport infrastructure construction. Existing road infrastructure, 
currently used for transit port purpose, can be used for ambulance car transportation - it has exit on the streets of Cara Hadrijana and Josipa Hutlera (Figure 3 and 4), but there can also be constructed direct access to the hospital complex from the north side.

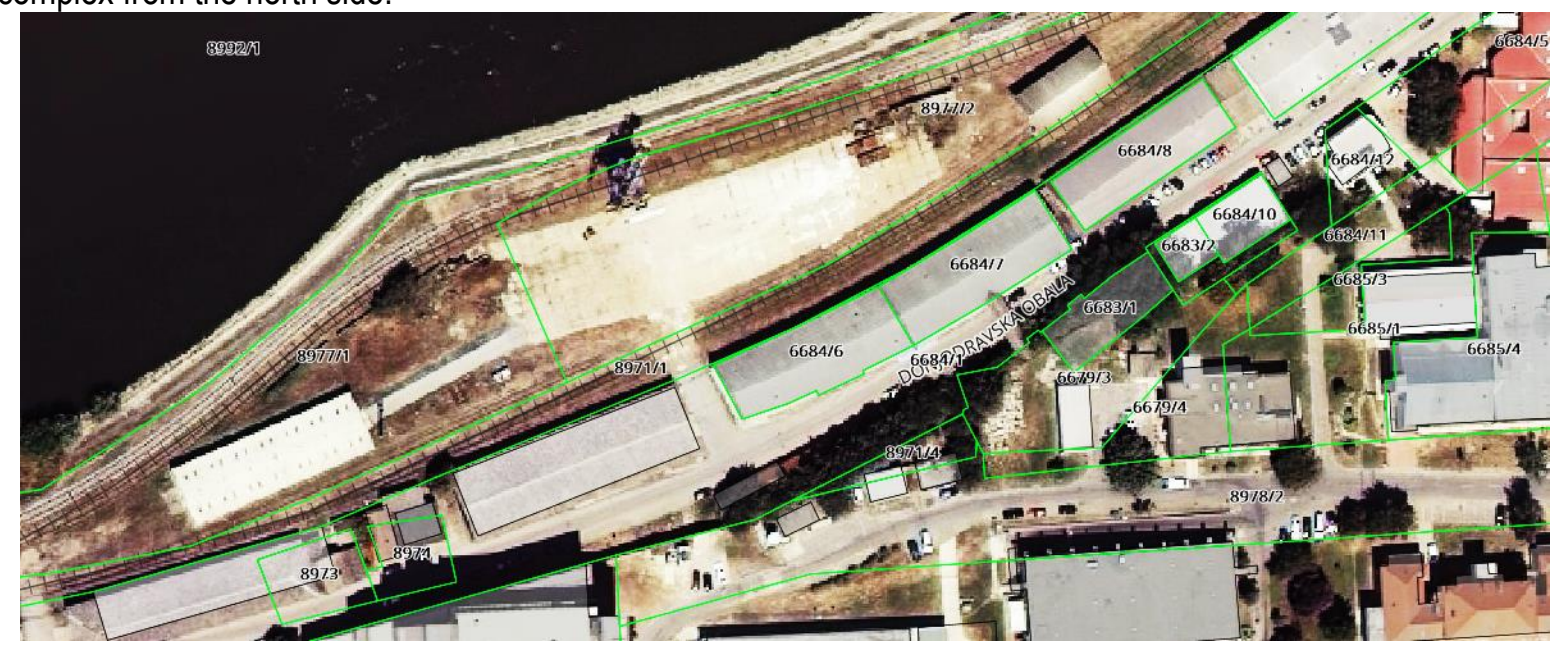

Figure 2 Location plan and plots for heliport construction [8]

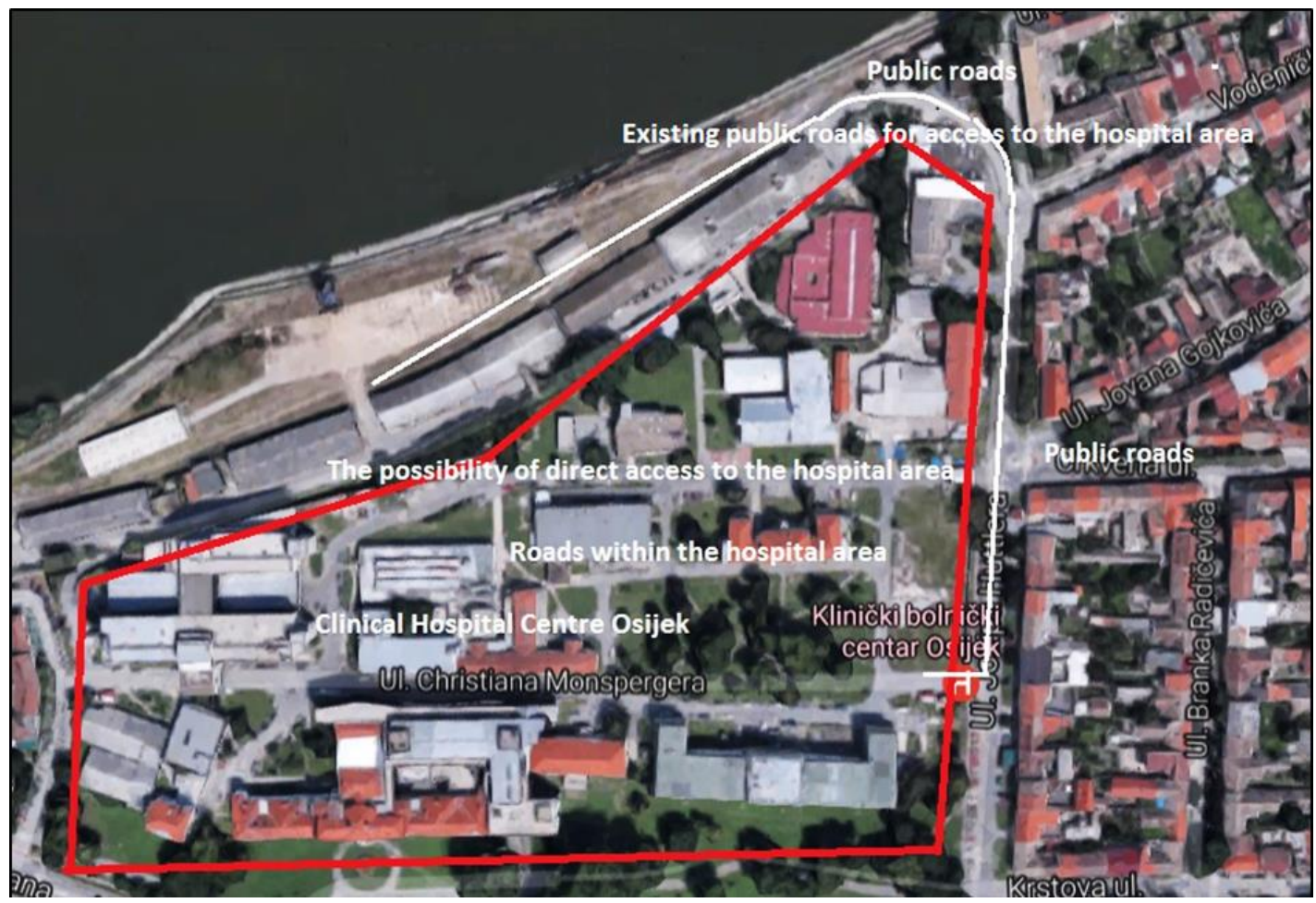

Figure 3 Existing road infrastructure [9]

\subsection{Dimensions of design helicopter}

For the purpose of the Clinical Hospital Centre heliport, chosen emergency helicopter is Eurocopter EC135, usually used for emergency medical transport. It is a light helicopter with weight of $2910 \mathrm{~kg}$ and the helicopter producing low noise margin about 6,5 dBA below the ICAO limit, which makes it the best option for urban environment. Dimensions of design helicopter are more detailed in master thesis [7] where overall dimension of helicopter is $D=12,16 \mathrm{~m}$, rotor dimension is $R D=10,20 \mathrm{~m}$, and undercarriage width dimension is $\mathrm{UCW}=2 \mathrm{~m}$. Helicopter is intended to be used for air taxiing operations because of his skids, but it is capable of taking ground-handling wheels [10]. 


\subsection{Variants of heliport conceptual design}

Recommendations for heliport design of National standards [2] are implemented in variants of heliport conceptual design for emergency medical service for the Clinical Hospital Centre in Osijek. Two variants of heliport designs were analyzed (Figure 4).

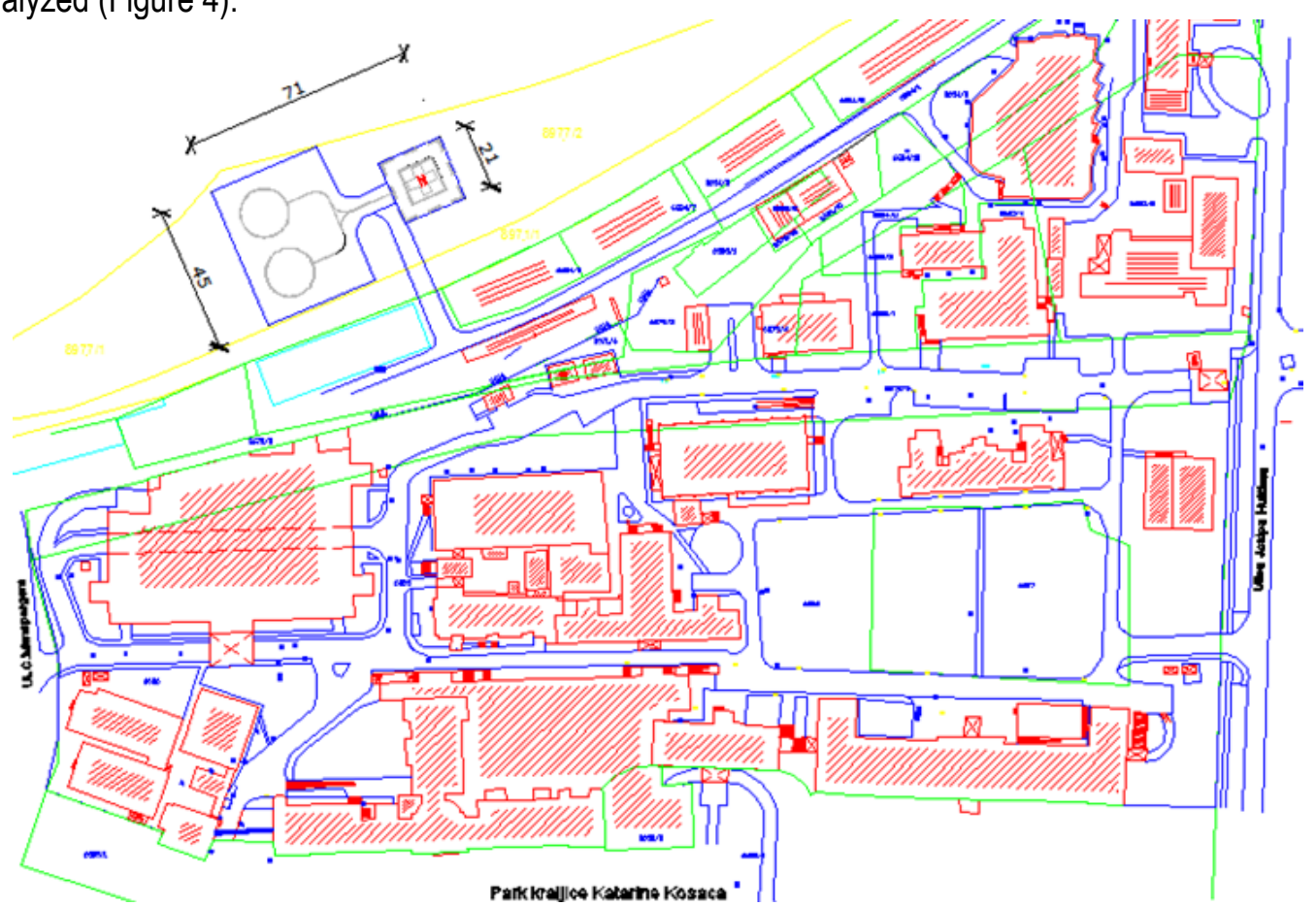

A - First variant

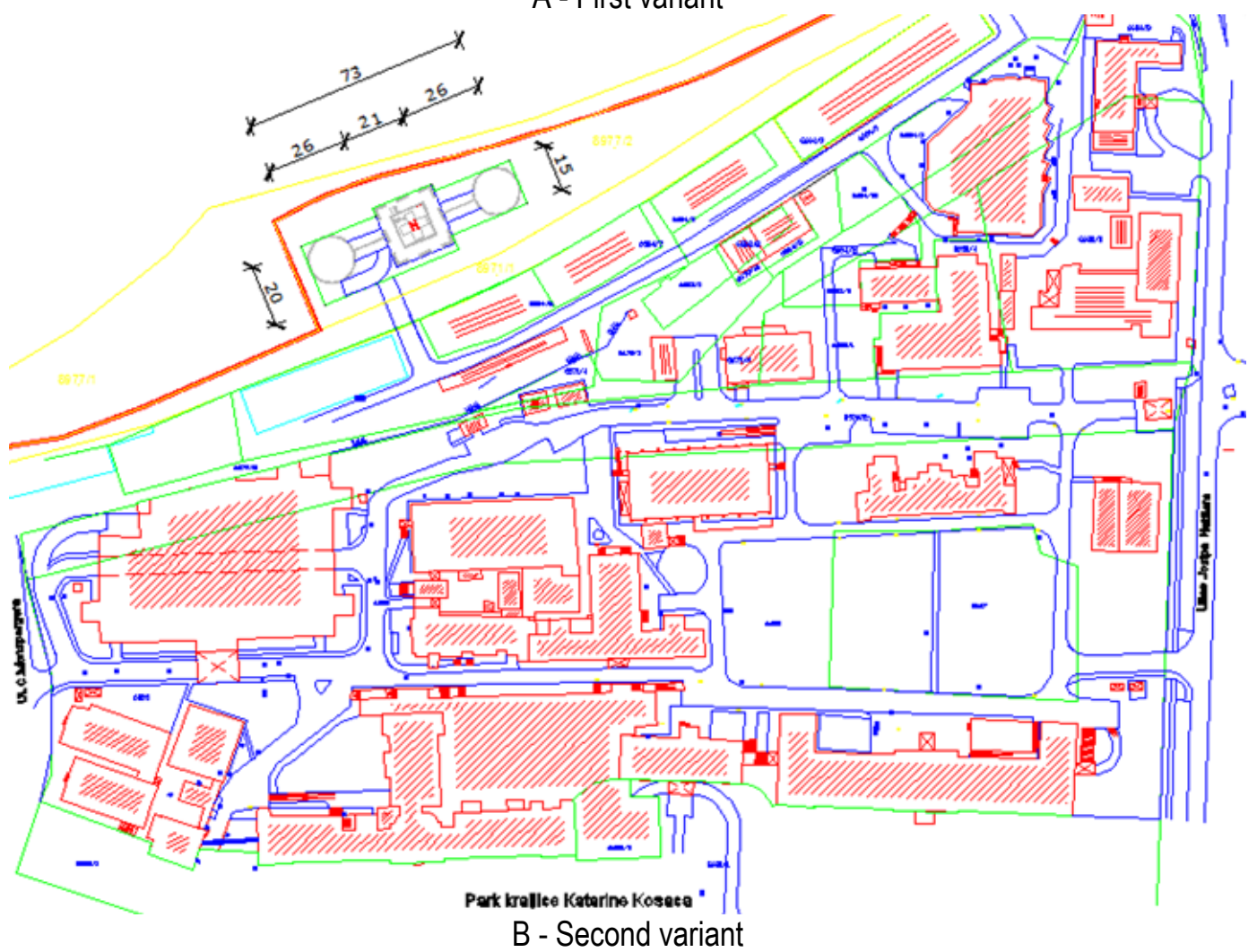

Figure 4 Heliport variants [7] 


\subsubsection{First variant of heliport conceptual design}

Ground level heliport variant is planned on two connected plots 8977/1 and 8977/2 (Figure 4a). Required area for heliport is cca $71 \times 45 \mathrm{~m}$, including the apron with two parking positions which are not designed for simultaneous turning helicopter operations.

Ground level heliport is limited in space, because it has to be constructed 3 meters below the hospital complex. Helicopter take-off and landing operations are possible only in one, north direction, from the river Drava. Only one approach and take-off surface can be constructed. Example of approach and take-off surface for ground level heliport is presented in the Figure 5.

Dimensions of FATO, TLOF, safety area, taxi-way and apron were chosen according to dimensions of design helicopter. Elements are presented in the Figures 6 and 7, and explained more detailed in master thesis [7]. Horizontal visual aids are designed in a way presented in the Figure 7.

\section{LAYOUT}

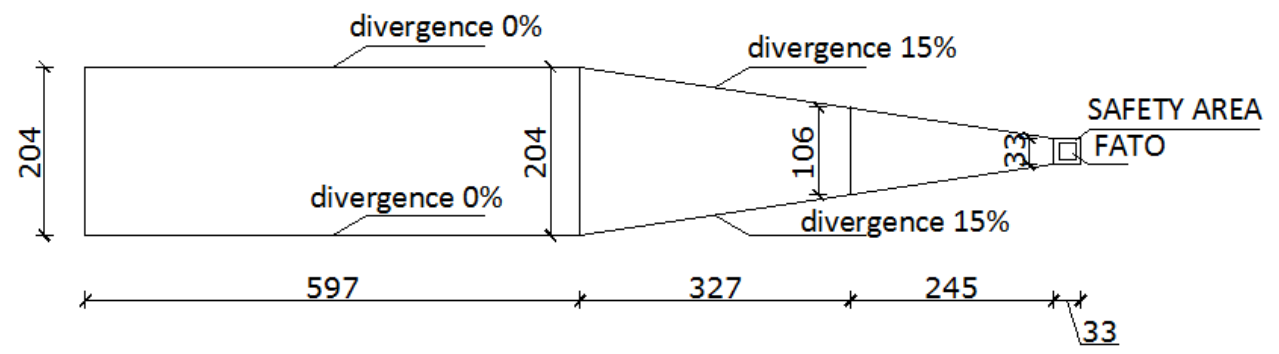

CROSS-SECTION

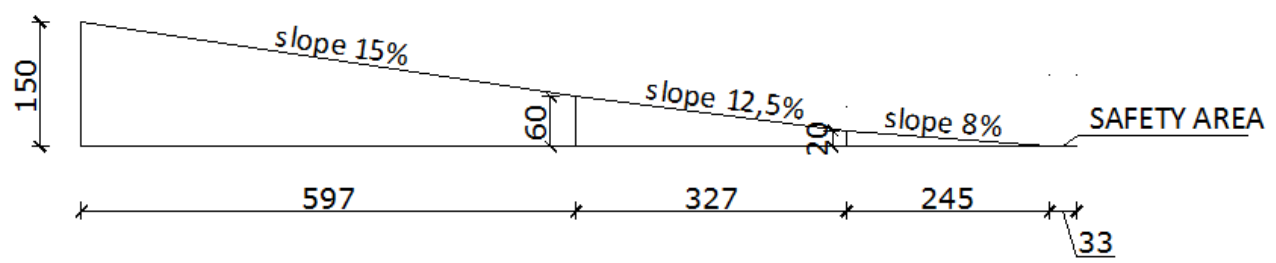

Figure 5 Limitation obstacle surfaces - ground level heliport
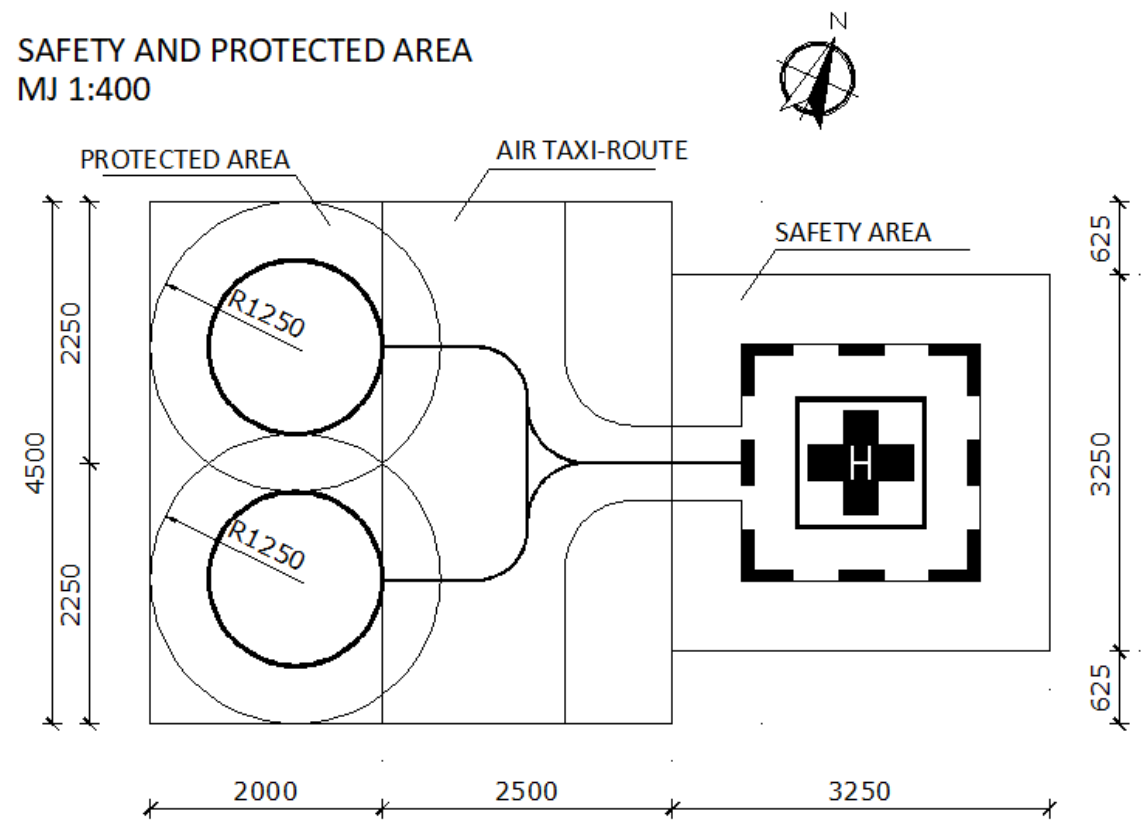

Figure 6 Safety area, apron and taxi-way - ground level heliport 


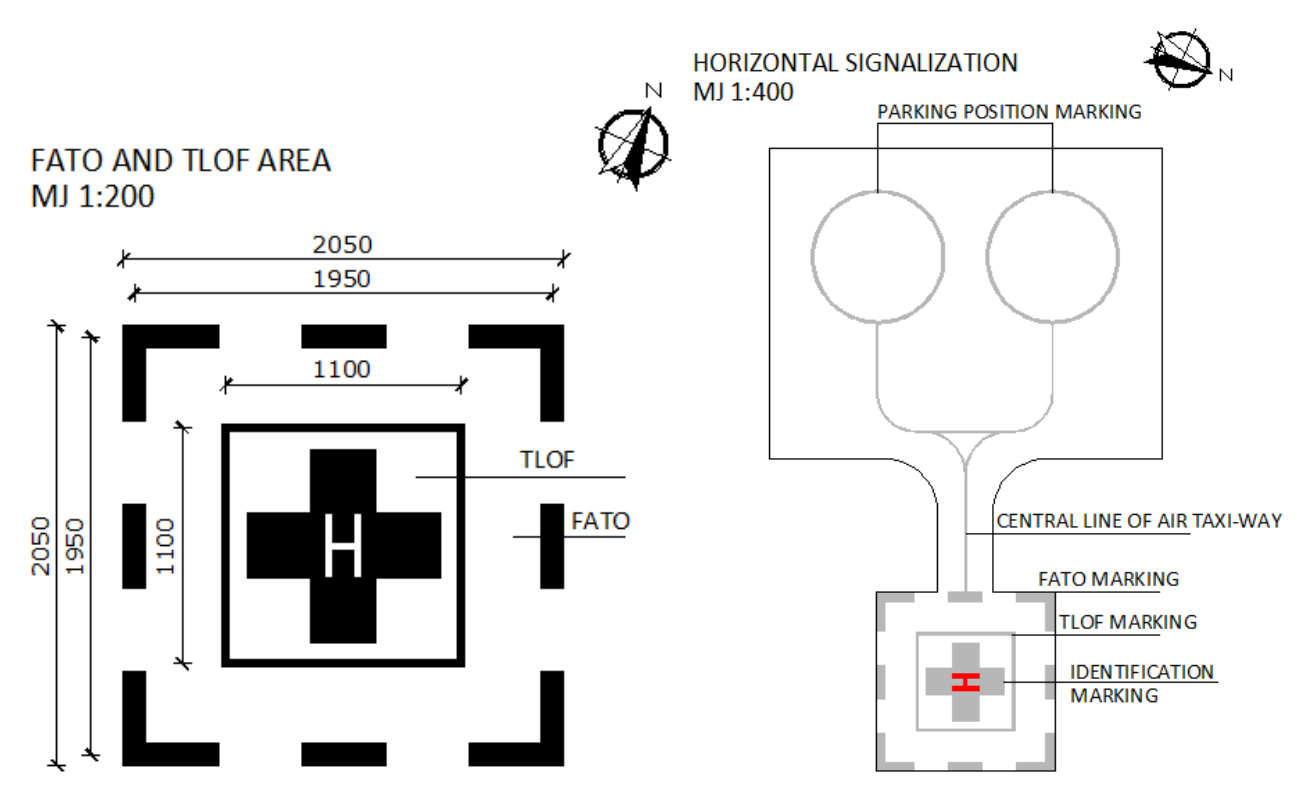

Figure 7 FATO and TLOF areas and horizontal visual aids - ground level heliport

\subsubsection{Second variant of conceptual heliport design}

Elevated heliport variant is planned on the roof of multy storey garage (basement + ground level) with required area cca 70x20, on the plot 8977/2 (Figure 4b). Heliport includes TLOF and FATO areas with two parking positions placed in the way presented on Figure 8. Approach to the roof is planned with a curve ramp as a part of garage.

It is possible to provide two approach and take-off surfaces for the roof-top heliport aimed for the helicopter operations in visual flight conditions, but there is also enough space for roof-top helistop designed for helicopter operations in instrument flight conditions. Taking off and landing operations are planned in two directions, north and south, but preferred direction is on the north side where the river Drava is. Examples of approach and take-off surfaces for elevated heliport are presented in the Figure 9.

\section{SAFETY AND PROTECTED AREA \\ MJ 1:400}
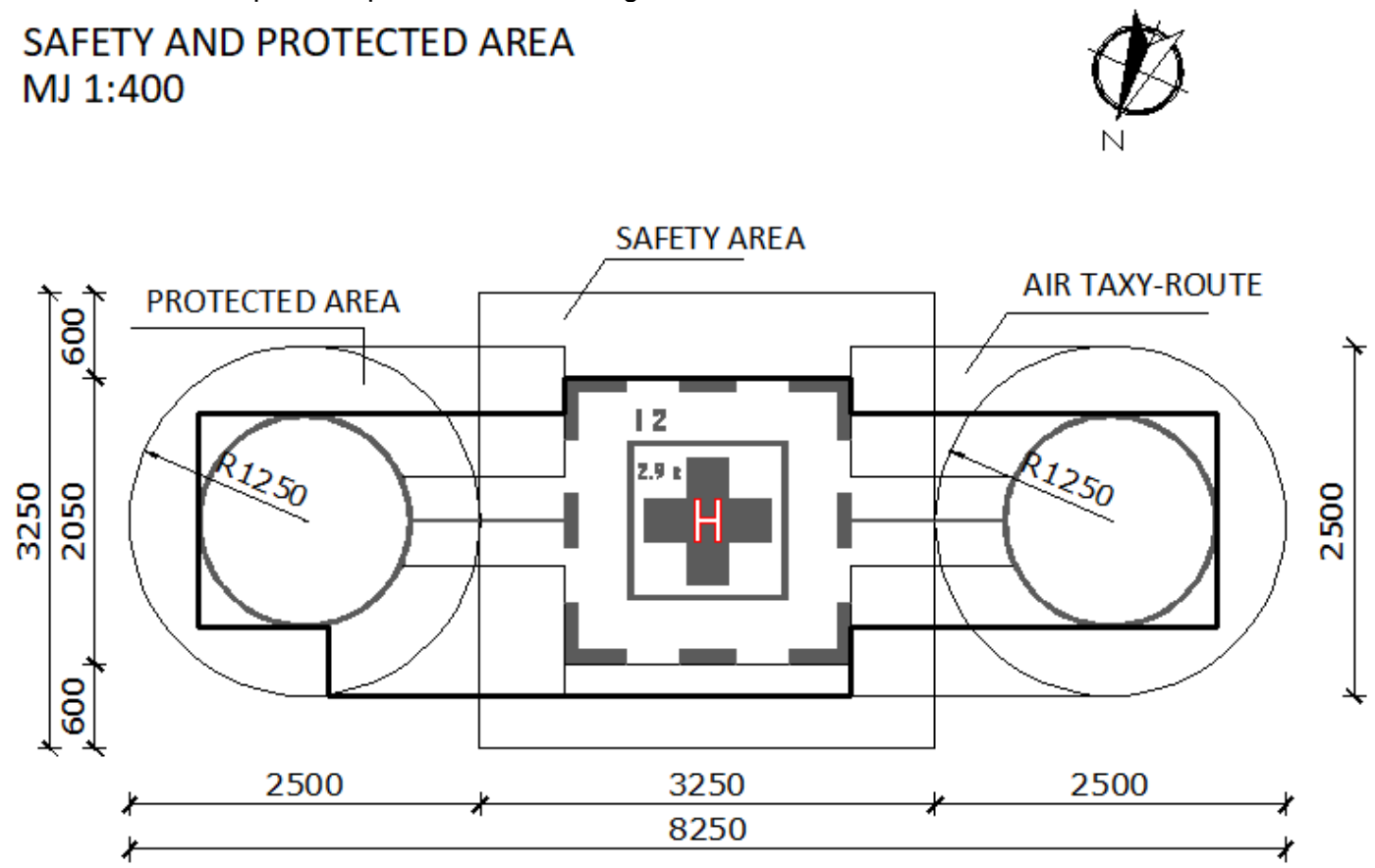

Figure 8 Safety area, parking positions and taxi-ways - elevated heliport 
LAYOUT
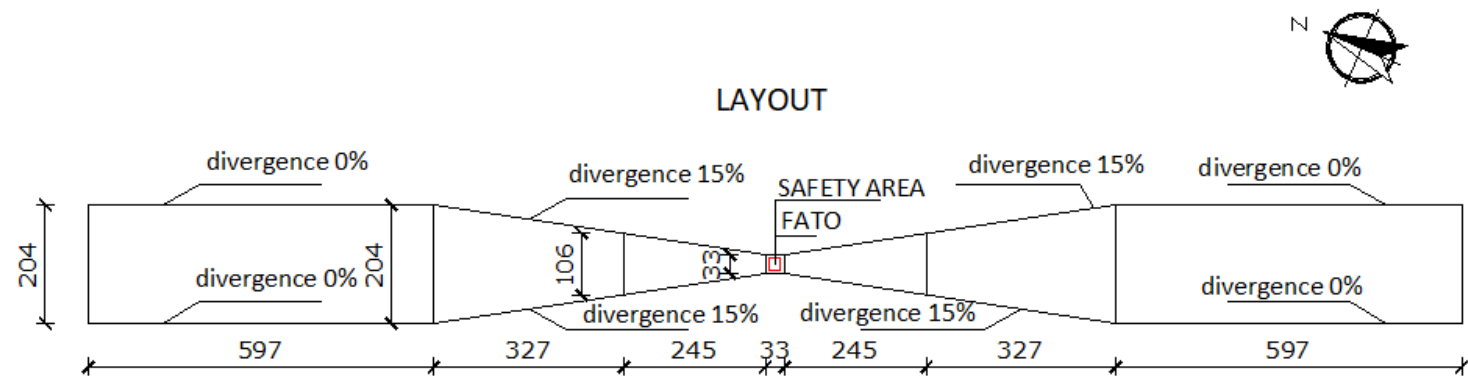

CROSS-SECTION

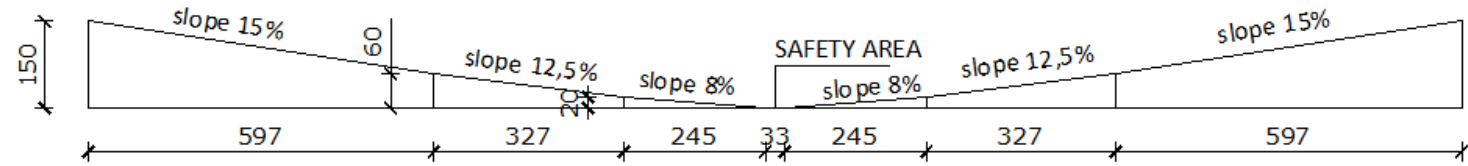

Figure 9 Limitation obstacle surfaces - elevated heliport

Dimensions of FATO, TLOF, safety area, taxi-ways and parking positions were chosen according to dimensions of design helicopter. Elements are presented in the Figures 8 and 10, and explained more detailed in master thesis [7]. Horizontal visual aids are designed in a way presented in the Figure 10.

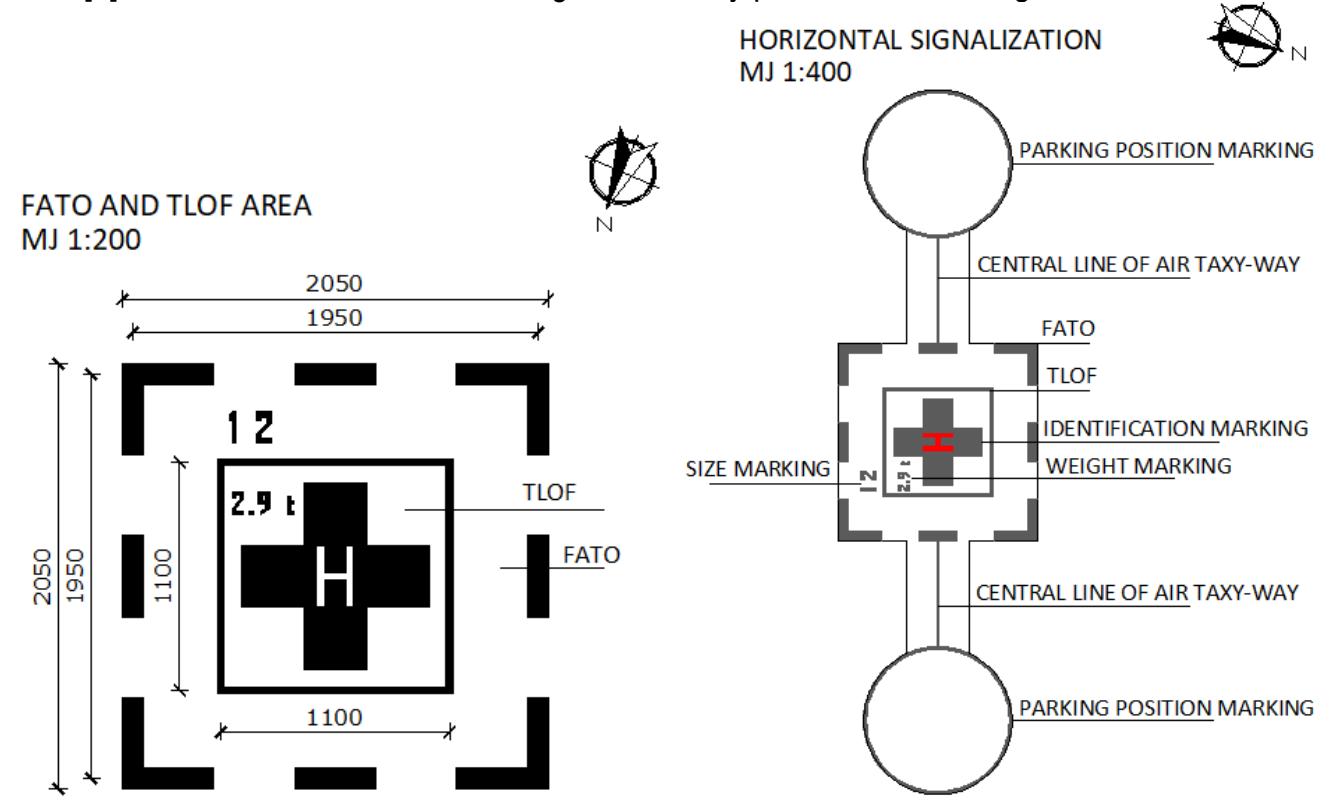

Figure 10 FATO and TLOF areas and horizontal visual aids - elevated heliport

\section{COMPARISON OF CONCEPTUAL HELIPORT DESIGN VARIANTS FOR THE CLINICAL HOSPITAL CENTRE IN OSIJEK}

In order to adopt better solution, considering the conditions of location near Clinical Hospital Centre in Osijek, it's necessary to compare these two conceptual designs. They are analyzed upon the criteria of air and ground accessibility, security of helicopter operations and possibility for instrument flight conditions at heliport, size of heliport and necessary areas, costs of building and maintaining and helicopter noise. 


\subsection{Air accessibility}

Elevated heliport is better variant upon the criterion of the air accessibility. National recommendations [2] demand establishing at least two approach/departure paths separated 150 degrees. Ground level heliport variant is limited in space and therefore helicopter operations are possible only in one direction, from the side of river Drava. Elevated heliport solution gives the possibility for establishing two approach/departure paths, and covers the area from the city and from the river Drava, what makes this solution better.

\subsection{Ground accessibility}

Ground level heliport is better variant upon the criterion of the ground accessibility. Elevated heliport is planned on the roof of the multy storey garage, therefore the distance ambulance cars need to pass is longer, from ground to the roof, which can be non-practical because of the narrow ramp. Ground level heliport has the better accessibility for ambulance cars, because they can directly pass to the helicopter taxi-way and FATO area.

\subsection{Size of heliport}

Both heliport solutions require large areas with length of around 70 meters. Width of ground level heliport variant, which includes apron with two parking positions for helicopters, amounts $45 \mathrm{~m}$. Therefore, it is only possible to build heliport on two connected plots, 8977/1 and 8977/2. Roof-top heliport variant is longer, with two individual parking positions on the each side of the FATO area that are not used for taking-off and landing helicopters. Width of the necessary space, which amounts 20 meters, is two times smaller than ground level heliport variant and therefore it is possible to build heliport on just one plot, 8977/2.

\subsection{Instrument approach}

Construction of heliport for instrument flight conditions demands much larger safety area and establishing of all limitation obstacle surfaces. While ground level heliport variant does not have the possibility for instrument flight conditions, elevated heliport has, but in this solution it is not displayed. Because of the location of heliport, which is in urban environment and three meters below the hospital complex, buildings and road infrastructure allow no construction of instrument approach on the ground. There is possibility for making instrument approach on the roof of the garage, but it also demands increasing the height of building and constructing more floors used for parking.

\subsection{Security}

Upon the criteria of secure air transport and air accessibility elevated heliport is better solution, where it is possible to establish two approach/departure paths, as recommended by National regulations [2]. Also, helicopter parking operations are more secure at elevated heliport because it is designed for simultaneous turning operations on parking areas. At the ground level heliport, protection areas of helicopter stands overlap and simultaneous turning operations are not allowed. On the other side, FATO area is more secure at ground level heliport because full safety area is placed on the ground. On the elevated heliport, safety area is in the air and during the emergency landing situations it can cause crashing helicopters into garage building.

\subsection{Costs of building and maintaining}

Building capable for helicopter reception doesn't exist on the location of transit port. For this reason it is necessary to build a structure for elevated heliport. In this paper heliport infrastructure is planned on the roof of a two storey garage. Construction of this building significantly increases the costs of building and maintaining the heliport. On the long-term, construction of garage can solve an issue of lack of parking space around hospital. Therefore, costs of building and maintaining ground level heliport are much lower in comparison with roof-top heliport, but construction of garage has its benefits looking on the long-term. 


\subsection{Noise}

Both heliport solutions are planned at the location of transit port, uninhabited place, but hospital complex is placed around 100 meters above. Therefore it's possible to expect the same noise level on the both designs but it can be minimized by using a quiet emergency helicopter.

\subsection{Comparison}

Table 3 shows comparison of heliport variants according to above-mentioned criteria. Therefore, the better solution is elevated variant, which provides better security and accessibility and also takes less required area for construction. Final decision is upon the investor if they choose one of the offered designs.

Table 3 Analysis of conceptual heliport designs

\begin{tabular}{ccc}
\hline CRITERIA FOR EVALUATION & GROUND LEVEL HELIPORT & ELEVATED HELIPORT \\
\hline Air accessibility & - & + \\
Ground accessibility & + & - \\
Size of heliport & - & + \\
Instrument flight conditions & - & + \\
Security of air transport & - & + \\
Security on parking positions & - & + \\
Security of FATO area & + & $+/-$ \\
Noise & $+/-$ & +
\end{tabular}

\section{CONCLUSION}

Clinical Hospital Centre in Osijek is a Health care Centre whose patients are from the whole east region of Croatia. It is also an important transplantation center, what makes consideration about heliport close to hospital justified. Therefore, analyzed locations are close to the hospital and location of transit port is chosen, with good traffic connections.

In this paper, two conceptual solutions of heliports are elaborated and compared - ground level heliport and heliport at elevated surface, which doesn't exist, but is imagined to be on the roof of a multi-storied garage with possible access to the roof for ambulance cars. After analysis it is resolved that elevated heliport variant is better based on a number of criteria. Recommendations of National heliport regulations (Pravilnik o helidromima NN 24/11) [2] that are based on standards and recommendations of International Civil Aviation Organization (ICAO) [3], are implemented in the case of heliport in Osijek.

\section{References}

[1] https://www.google.hr/maps/dir/Klini\%C4\%8Dki+bolni\%C4\%8Dki+centar+Osijek/Aerodrom+Osijek\%C4\%8Cepin+(LDOC)/@45.5348763,18.6683032,12.67z/data=!4m13!4m12!1m5!1m1!1s0x0:0xc77981214900d454!2 m2!1d18.7117456!2d45.5582335!1m5!1m1!1s0x0:0xd64d19c9bcba8002!2m2!1d18.646072!2d45.541463?hl=hr Accessed 30 August 2016

[2] Zakon o helidromima, NN 24/11 (in Croatian)

[3] International Civil Aviation Organization - ICAO 2009.: Aerodromes, Volume II, Heliports, Annex 14 to the Convention on International Civil Aviation

[4] Federal Aviation Administration 2012:: Advisory Circular 150/5390-2C

[5] Leverton J. 2012: ICAO „Annex 14 update“ workshop, HAI HeliExpo 2012, 11.-14.02.2012.

[6] Federal Aviation Administration 2013.: Advisory Circular 150/5345-27

[7] Timko T. 2016.: Projektne preporuke u projektiranju helidroma, Final thesis, University of Osijek, Faculty of Civil Engineering Osijek, (in Croatian)

[8] http://geoportal.dgu.hrl Accessed 30 August 2016

[9] https://www.google.hr/maps/@45.558758,18.714422,374m/data=!3m1!1e3 Accessed 30 August 2016

[10] Eurocopter an EADS Company: Eurocopter EC135 Technical data, Eurocopter an EADS Company, 01/2006 